\title{
Blackness Visible
}


Also by Charles W. Mills:

The Racial Contract 


\section{Blackness}

Visible

Essays on Philosophy and Race

Charles W. Mills

Cornell University Press Ithaca and London 


\section{Copyright 1998 by Cornell University}

All rights reserved. Except for brief quocations in a review, this book, or parts thereof, must not be reproduced in any form without permission in writing from the publisher. For information, address Cornell University Press, Sage House, s12 East State Street, Ithaca, New York 14850.

First published 1998 by Cornell University Press

First printing, Cornell Paperbacks, 1998

Cornell University Press strives to use environmentally responsible suppliers and materials to the fullest extent possible in the publishing of its books. Such materials include vegerable-based, low-VOC inks and acid-free papers that are recycled, totally chlorine-free, or partly composed of nonwood fibers. Books that bear the logo of the FSC (Forest Stewandship Council) use paper taken from forests that have been inspected and certified as meeting the highest standards for environmental and social responsibility. For further information, visit our website at www.cornellpress.comell.edu.

Cloth printing 10 987654321

Paperback printing 10 9876543
Library of Congress Camaloging-in-

Publication Data

Mills, Charles W. (Charles Wade)

Blackness visible : escays on philosophy and race / Charles W. Mills.

p. $\mathrm{cm}$.

Includes index.

ISBN 0-8014-3467-X (cloth : alk. paper). -ISBN 0-8014-8471-s (pbk. : alk. paper)

I. United States-Race RelationsPhilosophy. 2. Afro-American philosophy. 3. Racism-United StatesPhilosophy. 4 Afro-Amerians-Race identity. s. Afrocentrism. 1. Title.

E185.615.M54 1998

305. 8'00973--dc21 $97-45768$ 
Toward a better vision for the world 

I am invisible, understand, simply because people refuse to see me ... because of a peculiar disposition of the eyes of those with whom I come in contact. A matter of the construction of their inner eyes.

- Ralph Ellison, Invisible MaN 
